\title{
Goat genetic resources and breeding strategies in Thailand
}

\author{
Suwit Anothaisinthawee ${ }^{1}$ Koh Nomura ${ }^{2}$ Takao Oishi ${ }^{2}$ and Takashi Amano ${ }^{2}$
}

1 Animal Husbandry Division, Department of Livestock Development, Bangkok, Thailand

2 Laboratory of Animal Genetics and Breeding, Graduate School of Agriculture, Tokyo University of Agriculture, Kanagawa, Japan

\section{タイ国における家畜ヤギ遺伝資源とその育種戦略}

\author{
スウィト・アノタイシンタウィー 1 、野村こう 2 、大石孝雄 2 、天野卓 2 \\ 1 タイ国畜産局畜産振興課、バンコク タイ \\ 2 東京農業大学大学院農学研究科家畜育種学研究室、神奈川県
}

\section{Introduction}

Thailand is the 50th largest country in the world with a total area of approximately $513,000 \mathrm{~km} 2(198,000 \mathrm{mi} 2)$. It is the 21 st most populous country with approximately 64 million inhabitants. The tropical climate in Thailand is dominated by monsoons and is characterized by high temperature and humidity. Although northern, northeastern, eastern and central Thailand have 3 seasons (summer, rainy and winter), southern Thailand has 2 seasons (summer and rainy). The national religion is Buddhism; however, approximately 10 percent of the population or 6.4 million inhabitants are Muslims, concentrated largely in the southern border provinces. Chickens accounted for the largest country is relatively small $(374,029)$; however, in the past 8 years, it has increased markedly at a rate of $22.74 \%$ per annum, especially in the central $(42.12 \%)$ and Northeast (36.87\%) parts of the country (Table 1). Goats are predominantly raised by smallholders, particularly those in the Muslim community for religious and ritual slaughter. Farmers, classified as traditional or subsistence, commonly use low-input methods (such as graze crop residues or natural pasture) throughout the region. Goats in Thailand are predominantly used for meat production (90\%), while milk production is a relatively small industry $(10 \%)$. Goat raising is expanding following the demands of Malaysia as well as the government promotion strategies by the Department of

Table 1. Goat population of Thailand by region, 2001 - 2008.

\begin{tabular}{|c|c|c|c|c|c|}
\hline Year & Central & Northeast & North & South & Total \\
\hline 2001 & 37,789 & 12,295 & 24,134 & 114,279 & 188,497 \\
\hline 2002 & 37,356 & 4,573 & 29,579 & 106,436 & 177,944 \\
\hline 2003 & 52,967 & 5,021 & 43,410 & 112,519 & 213,917 \\
\hline 2004 & 62,950 & 12,354 & 39,729 & 135,043 & 250,076 \\
\hline 2005 & 109,681 & 13,974 & 55,310 & 159,390 & 338,355 \\
\hline 2006 & 111,742 & 15,014 & 56,149 & 141,245 & 324,150 \\
\hline 2007 & 162,926 & 21,423 & 86,373 & 174,052 & 444,774 \\
\hline 2008 & 158,487 & 20,901 & 53,702 & 140,939 & 374,029 \\
\hline Increase (\%) & 42.12 & 36.87 & 9.60 & 3.87 & 22.74 \\
\hline
\end{tabular}

Source:DLD (2008)

proportion of the country' s livestock inventory in 2008 $(84.92 \%)$, followed by ducks $(8.19 \%)$, beef cattle $(3.28 \%)$, swine $(2.79 \%)$, buffalo $(0.49 \%)$, dairy cattle $(0.17 \%)$, goats $(0.13 \%)$ and sheep $(0.02 \%)$. The goat population in the
連絡先: Suwit Anothaisinthawee

Animal Husbandry Division, Department of Livestock Development, Phayatai Rd, Ratchatavee, BKK 10400 Thailand (email: breeding5@dld.go.th) 
Livestock Development (DLD) responsible for livestock production and health services under the Ministry of Agriculture and Cooperatives (MOAC).

\section{Goat genetic resources}

Goats in Thailand are predominantly used for meat $(90 \%)$ and milk production is a smaller industry $(10 \%)$. This paper reviews the literature on animal genetic resources (AnGR) and the national plans and strategies for improving goat breeding. Native goats are genetic resources that can be crossed with exotic breeds to produce rangeland goats for more extensive production. Approximately 10 goat breeds exist in Thailand: 2 indigenous and 8 exotic. There are 4 meat breeds and 4 dairy breeds (Table 2). The 2 local goat breeds are the Northern Thai referred to as 'Bangala', which has a large but thin body, long pendulous ears (similar to the Anglo-Nubian) and a straight face profile, and the other is the Southern Thai referred to as 'Katjang', which is small in size with short upright ears (similar to the Katjang goat found throughout Southeast Asia).

\section{Local breeds}

\subsection{Northern Thai native goat (Bangala)}

Bangala have short hair except for on the thigh and back leg where hair is long. Coat colours and patterns vary. Body weight at birth, 3, 6 and 9 months of age is $2.20 \pm$ $0.10,11.88 \pm 0.74,15.63 \pm 0.83$ and $25.32 \pm 1.10 \mathrm{~kg}$, respectively. Average adult height at the withers is $80 \mathrm{~cm}$ for males and $70 \mathrm{~cm}$ for females, and mature weight is $45 \mathrm{~kg}$ for males and $35 \mathrm{~kg}$ for females. Slaughter of yearlings yields a dressing percentage of $50.84 \pm 1.04 \%$. Milk production is $543 \pm 40$ gm per day. The lactation period is $129.16 \pm 5.43$ days (Bunlengthong \& Sirisom 2003). The Bangala may be a breed from Bangladesh or India or a crossbreed that was

Table 2. Breeds of goats in Thailand

\begin{tabular}{|c|c|c|c|c|}
\hline No. & Breed & $\begin{array}{l}\text { Developed by/ } \\
\text { country of origin }\end{array}$ & $\begin{array}{l}\text { Imported to } \\
\text { Thailand }\end{array}$ & $\begin{array}{l}\text { Description and Distribution } \\
\text { in Thailand }\end{array}$ \\
\hline & \multicolumn{4}{|l|}{ Local Breeds } \\
\hline 1 & $\begin{array}{l}\text { Northern Thai } \\
\text { Native goat } \\
\text { (Bangala) }\end{array}$ & $\begin{array}{l}\text { Northern region, } \\
\text { Thailand }\end{array}$ & $\begin{array}{l}\text { Descended from } \\
\text { nomadic goats of } \\
\text { India, Myanmar }\end{array}$ & $\begin{array}{l}\text { Large size, using as a base } \\
\text { resource, mainly found in the } \\
\text { north and central regions. }\end{array}$ \\
\hline \multirow[t]{2}{*}{2} & $\begin{array}{l}\text { Southern Thai } \\
\text { Native goat } \\
\text { (Katjang) }\end{array}$ & $\begin{array}{l}\text { Southern region, } \\
\text { Thailand }\end{array}$ & $\begin{array}{l}\text { Descended from } \\
\text { nomadic goats of } \\
\text { Malaysia }\end{array}$ & $\begin{array}{l}\text { Small size, large numbers } \\
\text { have been graded up, mainly } \\
\text { found in south region. }\end{array}$ \\
\hline & \multicolumn{4}{|l|}{ Meat Breeds } \\
\hline 3 & Anglo-Nubian & Britain & $\begin{array}{l}1982 \text { (UK) } \\
1988,1993,1997 \\
\text { (USA) } \\
2007 \text { (Australia) }\end{array}$ & $\begin{array}{l}\text { It is a useful dual purpose } \\
\text { breed that has a good capacity } \\
\text { to adapt to hot climate, found } \\
\text { all the country }\end{array}$ \\
\hline 4 & Boer & South Africa & $\begin{array}{l}1996-1997 \\
\text { (South Africa) } \\
2007 \text { (Australia) }\end{array}$ & $\begin{array}{l}\text { Colors include white with red } \\
\text { head. The breed has been } \\
\text { selected for meat production, } \\
\text { found all the country. }\end{array}$ \\
\hline 5 & Black Bengal & $\begin{array}{l}\text { India, } \\
\text { Bangladesh }\end{array}$ & $\begin{array}{l}2005 \\
\text { (Bangladesh) }\end{array}$ & $\begin{array}{l}\text { Small size, quality for leather } \\
\text { Bred by Royal project. }\end{array}$ \\
\hline \multirow[t]{2}{*}{6} & Jamunapari & India & 2007 (Malaysia) & $\begin{array}{l}\text { Large size, tallest \& longest } \\
\text { ears. Bred by Royal project. }\end{array}$ \\
\hline & \multicolumn{4}{|l|}{ Dairy Breeds } \\
\hline 7 & Saanen & $\begin{array}{l}\text { Saanen Valley, } \\
\text { Switzerland. }\end{array}$ & $\begin{array}{l}1984 \text { (Australia) } \\
1985 \\
\text { (Netherlands) } \\
1997 \text { (USA) } \\
2007 \text { (Australia) }\end{array}$ & $\begin{array}{l}\text { Most popular dairy goat in } \\
\text { Thailand. Heavy milk } \\
\text { producers, mainly found in } \\
\text { central and south regions }\end{array}$ \\
\hline 8 & Alpine & Britain & $\begin{array}{l}1997 \\
\text { (USA) }\end{array}$ & $\begin{array}{l}\text { Suited to cooler climates with } \\
\text { low humidity, found in } \\
\text { central and south regions }\end{array}$ \\
\hline 9 & Toggenburg & $\begin{array}{l}\text { Obertoggenburg, } \\
\text { Switzerland }\end{array}$ & $\begin{array}{l}1997 \\
\text { (USA) }\end{array}$ & $\begin{array}{l}\text { Suited to cooler climates with } \\
\text { low humidity, found in } \\
\text { central and south regions }\end{array}$ \\
\hline 10 & Laoshan & $\begin{array}{l}\text { Shangdong, } \\
\text { China }\end{array}$ & $\begin{array}{l}2001,2006 \\
\text { (China) }\end{array}$ & $\begin{array}{l}\text { Similar to Saanen, bred by } \\
\text { Farm model, Royal project. }\end{array}$ \\
\hline
\end{tabular}


introduced from Myanmar many years ago.

\subsection{Southern Thai native goat (Katjang)}

Southern Thai native goats possess the natural characteristics of heat and tick tolerance and high fecundity, producing approximately 2.0 kids per litter after the first kidding, under a harsh environment. This rate is slightly lower than that of Katjang in Malaysia, where the birth rate is reported to be 2.2 kids per litter (DVS 2003). Common physical characteristics of the breed include a black, brown or red coat colour, sometimes with a few white patches, a long coarse mane, short neck and scimitar-shaped curved horns, well developed in both sexes. Body weight at birth, 3 , 6 and 9 months of age is $1.79 \pm 0.33,8.10 \pm 2.13,12.22 \pm$ 2.63 and $16.43 \pm 2.77 \mathrm{~kg}$, respectively (Anothaisinthawee et al. 2008).

Average height at the withers is $63 \mathrm{~cm}$ for males and $56 \mathrm{~cm}$ for females, and mature weight is $30 \mathrm{~kg}$ for males and $25 \mathrm{~kg}$ for females. Milk production is $422 \mathrm{gm}$ per day, and the lactation period is 144.25 days.

The native goats, although smaller than the exotic breeds, are well adapted to low-input extensive production systems, which have enabled them to survive under harsh conditions making them important resources for smallholders. The native goats also have non-seasonal breeding characteristics and multiple births. Prolificacy is one of their most economically important traits. Nakavisut et al. (2007) reported the average litter size of Southern Thai native goats to be $1.40 \pm 0.05$ kids per litter. The heritability estimate for litter size was low at $0.09 \pm 0.11$. Native goats inherit good resistance to tropical parasites and diseases as

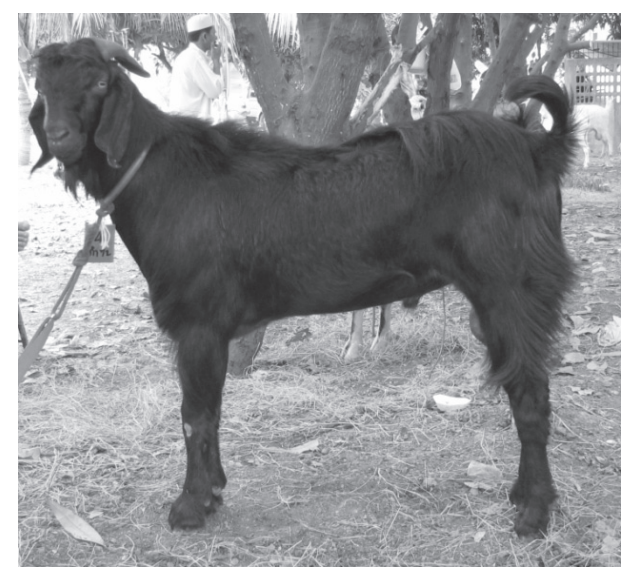

Northern Thai native (Bangala) well as tolerance of the hot and humid climate; however, they have lower meat yield and milk production compared to exotic breeds. Slaughter of adults yields a dressing percentage of $45-50 \%$. On the other hand, exotic breeds will not tolerate the tropical climate, parasites, diseases and the harsh environment, which makes the native goat a preferable source for the production of new breeds. Plans for conservation of animal diversity should include not only endangered and threatened domestic breeds, with little or no current use, but also breeds that are well used and involved in animal improvement programs (Barker 1997). Crossbreeding of native and exotic goats should increase production as well as income.

\section{Imported meat breeds}

\subsection{Anglo-Nubian goat}

The Anglo-Nubian has long, pendulous ears and a decidedly Roman nose. It is always short-haired. Solid or parti-coloured coats are found, but black, red or tan are the most common colours. A mature male stands at least $80 \mathrm{~cm}$ at the withers and weighs at least $60 \mathrm{~kg}$, while the female doe reaches a height of $75 \mathrm{~cm}$ and a weight of $50 \mathrm{~kg}$ or more. The Anglo-Nubian was the first exotic breed introduced to DLD stock in 1982. It is a relatively large and very useful dual-purpose milk and meat goat with a great capacity for adaptation to hot climates. The Winrock International Institute in the United States also presented 20 Nubian goats for His Majesty the King's projects in 1988. Five years later, the DLD imported 120 Nubians for breeding improvement. The Anglo-Nubian breeding season is much longer than that of the Swiss breeds making milk production possible year round. Although not a heavy milk

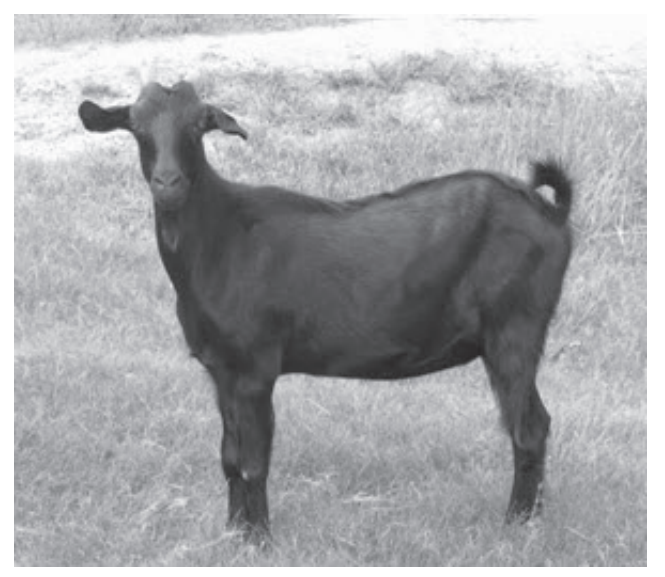

Southern Thai native (Katjang)

Fig. 1. Typical indigenous Thai goat breeds 
producer, it has a high average butter fat content. These goats are used for upgrading local breeds to obtain a dam line with increased milk and meat.

\subsection{Boer goat}

The Boer, a popular goat grown for its meat, was first introduced into Thailand in 1996. The Boer possesses strong disease resistance and is very adaptable to harsh environments. Weaning weights are high at $17.5 \mathrm{~kg}$, and they become sexually active at 7-8 months of age, at weights of $35 \mathrm{~kg}$ for bucks and $30 \mathrm{~kg}$ for does. Mature bucks weigh around 70-90 kg, and mature does weigh around $60-80 \mathrm{~kg}$. Fertility is high at an average of $130 \%$ and may increase up to $150 \%$. Boer goats also have a high meatproducing potential with carcasses of acceptable quality. The dressing weight percentage is more than $50 \%$. The Boer is crossed with other breeds to increase size, carcass weight and yield.

\section{National policy on goat production}

A common problem among farmers is their limited access to improved livestock due to lack of availability of high performance breeds. Most of the commercially raised livestock breeds are imported to improve dressing percentage and body weight, putting the farmers under an added disadvantage with production costs. To address this issue, the DLD aimed to supply Thai farmers with a stock of 50,000 heads each year, of native goats crossbred with Boer stock which grew larger and faster and were more fertile.

The policy includes research and development of technology for production, animal health, increasing product and accelerated extension of services to farmers. For the purpose of improving goat breeding, the DLD is now looking at genetic research to minimize production costs, optimize productivity and assist in accommodating consumer preference. The DLD has assumed an important role in the selection and introduction of breeding stock to develop and improve the native goat breeds that perform well in terms of growth and quality. The DLD is also concentrating on producing parent stock for farmers to try and reduce imported stocks. Specifically, the policy on goat production is intended to 1) promote goat development using a breeding strategy based largely on selection for fertility and meat production; 2) promote the distribution of good quality feed; 3) increase meat production for domestic consumption and share the surplus with neighbouring countries; 4) encourage development in livestock investment; and 5) upgrade the socio-economic status of the communities dependent on livestock.

\section{Research on goat breeds and improvement}

Crossbreeding has been used to combine breed attributes and hybrid vigour to increase animal production. The efficiency of different systems of breed utilization involves genetic effects. Characterization of breed, heterosis and recombination effects are fundamental for efficient use of genetic resources in a crossbreeding system. The optimal use of genetic resources and the comparative efficiency of different crossbreeding systems are determined by variation among breed effects relative to the magnitudes of heterosis and recombination effects (Cassady et al. 2002). Kantanamalakul et al. (2008a) reported that Nubian and Saanen additive breed effects were important for preweaning growth traits. Estimates of direct additive breed effects for birth weights of Nubian and Saanen were $0.41 \pm$ 0.11 and $1.21 \pm 0.28 \mathrm{~kg}$, respectively, and the weaning weight of Nubians was $2.36 \pm 0.70 \mathrm{~kg}(\mathrm{P}<0.01)$. The results support the extensive use of the large size Nubian and Saanen goat breeds in developing countries to upgrade the size of indigenous goats (Shrestha \& Fahmy 2007).

An animal model estimating sire and dam breeding values simultaneously is widely used for genetic evaluations. This model requires known genetic and environmental components of (co)variance which are used to estimate genetic parameters such as heritability and correlation between traits. These parameters are essential for livestock improvement and breeding programs that aim to maximize production efficiency of animals and profit for farmers. Kantanamalakul et al. (2008b) reported that it was important to implement the correct model for estimation of variance components and genetic parameters for birth weight and weaning weight of kids. Models ignoring maternal genetic effects tended to underestimate direct heritability. Negative estimates of direct and maternal genetic covariance observations would have a negative impact on the predicted total selection response. Therefore, selection for growth performance traits should be based on genetic evaluation using models accounting for maternal genetic effects. 


\section{Strategies of goat breeding}

The development of breeding strategies for the improvement of meat goats should include more than genetic parameter estimates for what are considered economically important traits. The biological, cultural, statistical, socio-economic and management aspects should be important components of the decision-making process because goats are closely associated with the environment, religious rituals and sustainable development activities, varying from a few large herds in the transhumance system to many small herds around urban areas. The absence of adequate resources, essential services and facilities leads to difficulty in delivering performance testing programs across the country and to serious concerns regarding feasibility. Therefore, the ability to initiate successful genetic improvement programs under such circumstances presents one of the most challenging issues for goat meat production improvement.

Breeding strategies currently in progress have demonstrated success in achieving marginal financial gain by adding value to goat meat and meat products (Quartermain 1991). The national breeding strategies provide breeders of meat goats with a simple means of identifying, measuring and recording performance on the farm for use in the genetic improvement of their breeding stock. Potential breeding goats are evaluated on the basis of growth rates of offspring or in combination with reproduction of their dam. At the same time, sires and dams are evaluated on the basis of the performance of their offspring. Usually, there is also the provision for contemporary comparisons of kids from different herds based on their performance under uniform feeding and management conditions at test stations. Although crossbreeding has advantages in the short term, selection of animals with genetic merit as replacement parents would accelerate a genetic response resulting in enhanced performance during crossbreeding and formation of composite populations. In this context, parameter estimates for body weight at various ages, age at first kidding, kidding interval, service period, litter size, live weight at slaughter, hot carcass weight, dressing percentage and feed conversion in several meat breeds and their crosses are important. In national programs for genetic evaluation, mixed model methodologies used to determine EBVs for multiple traits can benefit from precise estimates of genetic parameters, performance records on parents and sibs, pedigree relationships among animals and across herd performance.

Animals with sufficient genetic merit can be disseminated across herds to achieve improved productivity not only for goats under sedentary, nomadic and seminomadic management but also in commercial herds used for the production of meat. Specific strategies for improvements in goat breeding are as follows:

a) collection of productive and reproductive performance records essential for genetic improvements to be used to evaluate the breeding value of stock;

b) genetic evaluation and genetic parameter estimation using BLUP technique (Henderson 1978) which can accurately evaluate both individual and cross-herd with phenotypic selection;

c) use of statistical models and adjustment of environmental factors to determine a suitable animal model to estimate important genetic parameters;

d) development of breed planning to avoid losing advantageous traits such as disease resistance, and optimal use of genetic resources for comparative efficiency of different crossbreeding systems to exploit dominance of favourable effects;

e) use of molecular techniques for selection assistance to increase accurate genetic progression such as selection of the gene for parasite resistance;

f) establishment of a goat information centre for breeding and improvement in Thailand (GICBIT).

The DLD was responsible for the implementation of GICBIT as the national genetic evaluation system for goats in 2007. In the past, selection had always been based on phenotype (external appearance), but now selection on a genetic basis is being used with the DLD system. The GICBIT provides a selection strategy and a set of tools for establishing Thai national goat herds. This is a major advantage of the project and something that will provide significant national benefits in the future.

The economic value of goats depends on growth performance, which can be measured and expressed as body weight at various ages. The growth traits at early ages in farm animals are known to be influenced by direct and maternal effects (Meyer 1992; Ligda et al. 2000). The direct effect refers to the consequence that an individual's own genes have on its performance, while the maternal effect 
refers to the dam's genotype for milking and mothering ability and the effect of environment on her maternal ability. Estimates of these components of variance are important to make informative genetic evaluations that are required for successful livestock improvement programs.

\section{Synthetic breed development}

The notion behind the development of synthetic breeds is that crossbreeding of indigenous goats or established breeds with one or more breeds demonstrating genetic merit in performance traits of economical importance will increase milk or meat production. There are 3 synthetic breeds (Table 3 ).

\section{DLD-1 and DLD-2 goats}

Utilization of fine genetic resources has been extended by the DLD. For the production system, the DLD implemented pure breeding and systematic crossbreeding with a specific plan and purpose. Pure breeding is intended to maintain fine genetic resources, while systematic crossbreeding is conducted to rationally use and expand resources to develop new breeds or strains with higher adaptability and better performance. Structured breeding uses native maternal breeds with better adaptability crossbred with exotic paternal breeds

demonstrating high performance and moderate adaptability. Boer or Nubian goats were crossed with native goats to develop the DLD-1 goat with fast growth for high meat production. Saanen goats crossed with native goats were used to develop the DLD-2 goat having good fertility and milk production for smallholder farms. The objectives for establishing DLD-1 and DLD-2 breeds were to assist the goat breeders in setting goals and forming guidelines to maintain and improve the breed and to provide for uniformity in production. These synthetic breeds had survivability, adaptability, fertility, good mothering ability and could survive under harsh conditions with low quality food. The improved AnGR produced at Government Livestock Stations is not adequate to meet the requirement of farmers, and in the last decade, the private sector imported large numbers of Saanen and Boer from Australia, New Zealand and China.

\section{Southern Thai meat goat}

The project 'Research and development of Thai meat goat in the south', was supported by the Agricultural Research Development Agency (ARDA) and implemented during 2005-2008 in 3 locations: Yala, Songkla and Trang. The objective was to establish a new breed of Thai meat goat that was well adapted to the environment in the south with high growth performance and excellent meat quality (Anothaisinthawee et al. 2008). It has been developed through the crossbreeding of Anglo-Nubian and native goats to produce the F1 generation (2-way cross). Selection mainly focused on achieving higher growth rates. The Anglo-Nubian $\times$ native does were crossed with Boer bucks to produce the $\mathrm{F} 2$ generation (3-way cross), which performed better as a Thai meat goat breed (Table 4).

\section{Performance testing}

The GICBIT was started in 2007. Goats from DLD stations and network farms were recorded and evaluated so that improved genetic material could find its way back to the commercial sector where it could be used to increase meat and milk production. Evaluations were made for growth (birth, gains from birth to weaning and weaning to marketing) and reproduction to aid in the selection of animals for meat production. These evaluations could also be used to predict trends that could be rectified early if necessary.

\section{Table 3. Synthetic breeds in Thailand}

\begin{tabular}{|l|l|l|l|}
\hline No. & \multicolumn{1}{|c|}{ Breed } & \multicolumn{1}{c|}{ Established } & Description and Distribution in Thailand \\
\hline 1 & $\begin{array}{l}\text { DLD-1 goat } \\
\text { (2-way crosses) }\end{array}$ & $\begin{array}{l}\text { 2004 } \\
\text { 5-6 generations of } \\
\text { inter se mating }\end{array}$ & $\begin{array}{l}\text { Selection focused on growth rate and meat } \\
\text { production for smallholders; low input. }\end{array}$ \\
\hline 2 & $\begin{array}{l}\text { DLD-2 goat } \\
\text { (2-way crosses) }\end{array}$ & $\begin{array}{l}\text { 2004 } \\
\text { 5-6 generations of } \\
\text { inter se mating }\end{array}$ & $\begin{array}{l}\text { Selection focused on growth rate and milk } \\
\text { production for small holders; low input. }\end{array}$ \\
\hline 3 & $\begin{array}{l}\text { Southern Thai } \\
\text { Meat goat } \\
\text { (3-way crosses) }\end{array}$ & $\begin{array}{l}\text { 2005 } \\
\text { 5-6 generations of } \\
\text { inter se mating }\end{array}$ & $\begin{array}{l}\text { Selection focused on higher growth rate and } \\
\text { quality meat production for commercial }\end{array}$ \\
\hline
\end{tabular}


Table 4. Body weight of goats of different breeds

\begin{tabular}{|c|c|c|c|c|c|c|c|c|c|}
\hline \multirow[t]{2}{*}{ Breed } & \multicolumn{4}{|c|}{ Number of goats } & \multicolumn{5}{|c|}{ Statistics } \\
\hline & Age & male & female & Total & Min & $\max$ & Mean & SD & CV (\%) \\
\hline \multirow{4}{*}{$\begin{array}{l}\text { Southern } \\
\text { Thai Native }\end{array}$} & BW & 502 & 472 & 974 & 0.80 & 3.50 & 1.79 & 0.33 & 18.7 \\
\hline & M3 & 428 & 402 & 830 & 3.00 & 15.50 & 8.10 & 2.13 & 26.5 \\
\hline & M6 & 299 & 204 & 503 & 6.20 & 21.50 & 12.22 & 2.63 & 22.2 \\
\hline & M9 & 225 & 105 & 330 & 9.50 & 27.20 & 16.43 & 2.77 & 18.3 \\
\hline \multirow{4}{*}{ Anglo-Nubian } & BW & 361 & 345 & 706 & 1.00 & 5.00 & 3.14 & 0.76 & 24.1 \\
\hline & M3 & 307 & 301 & 608 & 7.0 & 19.0 & 15.2 & 3.52 & 23.2 \\
\hline & M6 & 96 & 79 & 175 & 10.0 & 37.00 & 20.75 & 4.71 & 24.7 \\
\hline & M9 & 85 & 57 & 142 & 12.00 & 44.00 & 27.41 & 5.79 & 25.8 \\
\hline \multirow{4}{*}{ Boer } & BW & 376 & 413 & 789 & 1.00 & 5.50 & 3.32 & 0.69 & 20.9 \\
\hline & M3 & 302 & 320 & 622 & 8.40 & 30.00 & 15.8 & 4.14 & 26.1 \\
\hline & M6 & 128 & 85 & 213 & 12.50 & 38.00 & 21.56 & 5.39 & 25.0 \\
\hline & M9 & 93 & 55 & 148 & 16.00 & 44.00 & 29.35 & 6.45 & 22.0 \\
\hline \multirow{4}{*}{$\begin{array}{l}\text { Anglo-Native } \\
\text { (2-way crosses) }\end{array}$} & BW & 331 & 385 & 716 & 0.90 & 4.50 & 2.23 & 0.50 & 22.6 \\
\hline & M3 & 262 & 313 & 575 & 4.00 & 22.50 & 10.86 & 3.29 & 30.3 \\
\hline & M6 & 194 & 127 & 321 & 6.60 & 31.00 & 17.50 & 4.19 & 23.9 \\
\hline & M9 & 163 & 7 & 170 & 13.50 & 41.00 & 23.40 & 4.29 & 18.3 \\
\hline \multirow{4}{*}{$\begin{array}{l}\text { Boer- } \\
\text { Anglo.Native } \\
\text { (3-way crosses) }\end{array}$} & BW & 84 & 86 & 170 & 1.00 & 5.00 & 3.32 & 0.69 & 20.3 \\
\hline & M3 & 45 & 45 & 90 & 9.00 & 26.00 & 16.02 & 4.01 & 25.0 \\
\hline & M6 & 26 & 28 & 54 & 12.50 & 38.00 & 25.68 & 5.96 & 23.2 \\
\hline & M9 & 10 & 11 & 21 & 18.00 & 45.00 & 34.14 & 7.35 & 21.5 \\
\hline \multicolumn{2}{|c|}{ Total of Birth weight } & 1,654 & 1,701 & 3,355 & 0.80 & 5.50 & 2.59 & 0.87 & 33.5 \\
\hline \multicolumn{2}{|c|}{ Total of 3 month old wt } & 1,344 & 1,381 & 2,725 & 3.00 & 30.00 & 12.29 & 4.67 & 38.1 \\
\hline \multirow{2}{*}{\multicolumn{2}{|c|}{$\begin{array}{l}\text { Total of } 6 \text { month old wt } \\
\text { Total of } 9 \text { month old wt }\end{array}$}} & 743 & 523 & 1,266 & 6.20 & 38.00 & 16.91 & 5.87 & 35.3 \\
\hline & & 576 & 235 & 811 & 9.50 & 45.00 & 22.67 & 7.30 & 33.8 \\
\hline
\end{tabular}

Anothaisinthawee et al. (2008)

\section{Conclusion}

Finally, genetic improvement depends on how fast the superior animals spread through the general goat population. The most rapid and economical way to accomplish this is by incorporating modern reproductive technologies with selective breeding. A systematic genetic evaluation system for economic traits is also necessary.

Indigenous breeds are essentially the products of long-term natural selection and as such are better adapted to withstand tropical diseases and perform under low and medium input. They may have useful genes for prolificacy and disease resistance. Such utility genes and breeds must be identified, conserved and utilized. The country must have a specific policy focused on conservation of indigenous breeds of livestock. An area-specific approach should be adopted for effecting qualitative and quantitative improvement in goat breeding with aims of increasing body weight, reproductive efficiency, controlled mortality and improvement in milk yield. The main focus should be on selection of bucks and their distribution, backed up by sustainable programs.

Breeding strategies and management practices can be integrated with traditional farming practices to improve the performance of locally adapted breeds. Case studies illustrate that improving performance of locally adapted breeds will produce sustainable benefits, and that this approach will often produce more benefits than strategies involving replacement or crossing with exotic breeds. Crossbreeding should be restricted to low-yielding indigenous goat breeds. Emphasis should be on increasing body weight, improving reproductive efficiency and reducing losses due to mortality through better nutrition and breeding. Improved reproductive efficiency and reduced losses due to mortality would make additional kids available to be reared, thus contributing to increased meat production. A program of buck selection through large-scale screening of farmer's flocks should be taken up as a national program. Input with regards to genetics, data analysis and estimations of EBVs has enabled the efficient initiation of a national goat improvement program, including data recording, central database management, genetic theory, analysis of data and design of breeding programs. The DLD has now disbanded its central performance test program in favour of on-station and network farms selection using EBVs calculated by the GICBIT system. Newer breeding and reproductive technologies, including embryo transfer and the 
open nucleus breeding system, should also be integrated into breed improvement programs.

\section{Acknowledgments}

This review was supported by the Agricultural Research Development Agency, ARDA Golden Jubilee Ph.D. Scholars Project. We gratefully acknowledge Dr. Napavarn Noparatnaraporn the Director of ARDA and Mr. Preecha Somboonprasert the Director General of DLD for granting and encouragement.

\section{References}

AHD (Animal Husbandry Division). 2010. Annual report 2009. Department of Livestock Develoment, Bangkok, Thailand.

Anothaisinthawee S, Nopawong Na Ayudhaya J, Wiriyasombat C, Chatchawal T, Kerdmake P, Nakavisut S, Chaweewan K. 2008. Research and development of Thai meat goat in the south. Final report. 141. Department of Livestock Development, Bangkok, Thailand..

Barker JSF. 1997. Conservation of domestic animal diversity. Proc. Assoc. Advmt. Animal Breed Genetic 12th, 633-640.

Bunlengthong S, Sirisom P. 2003. Growth performance, carcass characteristics, fertility, milk yield of northern native goat and their crossbreds. http:/www.dld.go.th/ research-AHD/Webpage/2546/46(3)-0206-194.pdf

Cassady JP, Young LD, Leymaster KA. 2002. Heterosis and recombination effects on pig growth and carcass traits. Journal of Animal Science. 80(9): 2286-2302.

DLD (Department of Livestock Development). 2008. Yearly Statistics Report 2008. Ministry of Agricultural and Cooperative, Bangkok, Thailand. http://www.dld. go.th/ict/stat_web/yearly/yearly51/index $51 . h t m l$

DVS (Department of Veterinary Services). 2003. Animal genetic resources in Malaysia. 100. Ministry of Agricultural, Malaysia.

Henderson, C. R. 1978. Undesirable Properties of Regressed Least Squares Prediction of Breeding Values. Journal of Dairy Science. 61:114-120.

Kantanamalakul C, Sopannarath P, Duangjinda M, Anothaisinthawee S, Tumwasorn S. 2008a. Factors affecting birth weight and weaning weight of AngloNubian, Saanen, Native and Crossbred goats.
Proceeding of 47th Kasetsart University Annual Conference. 50-57.

Kantanamalakul C, Sopannarath P, Duangjinda M, Anothaisinthawee S, Tumwasorn S.

2008b. Genetic parameters for birth weight and weaning weight in Anglo-Nubian,

Saanen, native and crossbred goats. Kasetsart JournalNatural Science 42(4): 640-648.

Ligda C, Gabriilidis G, Papadopoulos T, Georgoudis A. 2000. Investigation of direct and

maternal effects on birth and weaning weight of Chios lambs. Livestock.

Meyer K. 1992. Variance components due to direct and maternal effects for growth traits of Australian beef cattle. Livestock Production Science. 31: 179-203.

Nakavisut S, Chaweewan K, Nopawong Na Ayudhaya J, Anothaisinthawee S. 2007. Study on BMP15 Gene and the prolificacy of Southern Thai native goats. http:// www.dld.go.th/research-AHD/Webpage/2550/50(2)0206-162.pdf

Quartermain AR. 1991. Evaluation and utilization of goat breeds. In: Maijala, K. (Ed.), 451-469. World Animal Science. B8. Disciplinary Approach. Elsevier, Amsterdam, The Netherlands.

Shrestha JNB, Fahmy MH. 2007. Breeding goats for meat production: 2. Crossbreeding and formation of composite population Small Ruminant Research, 67(2-3): 93-112. 